\title{
The International Competitiveness of Polish Agriculture
}

\author{
Matthew Gorton ${ }^{1}$ \\ Alina Danilowska ${ }^{2}$ \\ Slawomir Jarka ${ }^{2}$ \\ Slawomir Straszewski ${ }^{2}$ \\ Aldona Zawojska ${ }^{2}$ \\ Edward Majewski ${ }^{2}$ \\ ${ }^{1}$ Department of Agricultural Economics and Food Marketing, University of Newcastle, \\ Newcastle upon Tyne, NE1 7RU, \\ ${ }^{2}$ Faculty of Agricultural Economics, Warsaw Agricultural University (SGGW)
}

February 2001

\begin{abstract}
This paper considers the international competitiveness of agricultural production in Poland. Competitiveness was measured in terms of domestic resource cost (DRC) ratios for three farm sizes and eight commodities. The results highlight that for the period 1996 to 1998 Polish crop production was more internationally competitive than livestock farming. The most internationally competitive crops of those analysed were rapeseed and potatoes. During the period, however, international competitiveness worsened as international commodity prices fell. There is an inverse relationship between DRCs and farm size. This is an important result as Polish production is relatively fragmented and the degree of structural change has been slow.
\end{abstract}

\section{Acknowledgement}

This research was conducted as part of component A of the EU Phare project P9704-0103/04/13/17 which provided technical advice to the Ministerwo Rolnictwa Rozwoju Wsi (Ministry of Agriculture and Food Economy - MAFE) in shaping agricultural policies through economic analyses). 


\section{INTRODUCTION}

The ability of Polish agriculture to deal with rising competitive pressures from trade liberalisation and future accession to the EU will have a bearing on the overall macroeconomic fortunes of the nation as a whole. The agri-food sector is a major component of the Polish economy, accounting for 12 per cent of total exports, 30 per cent of employment and 9 per cent of GDP in 1998 (MAFE, 1999). Relative changes in competitiveness compared to international markets and existing EU members will have an effect on the development of agriculture and regional standards of living. This article considers two key questions: how internationally competitive is Polish agriculture? and how does price competitiveness vary between farm sizes? In dealing with these questions the main methodological approach employed is the estimation of domestic resource costs (DRCs).

The paper is organised as follows. The next section presents a brief overview of the structure of farming in Poland and how this has evolved during transition. Section 3 outlines the methodology employed for analysing competitiveness and the data used in the analysis are discussed in section 4. The DRC estimations are reported in section 5 and the conclusion outlines for which agricultural products Poland is internationally competitive.

\section{FARM STRUCTURES}

Unlike most other CEECs, Poland did not extensively collectivise its agriculture under communism. By 1989, private plots and family farms accounted for approximately eighty per cent of total agricultural area (TAA). State farms accounted for the remaining fifth of TAA. 
The privatisation of state farms began in 1991 with a special agency created to manage the process - the Agencja Wlasnosci Rolnej Skarbu Panstwa (AWRSP). The AWRSP has been responsible for administering and privatising agricultural properties that belonged to the state as state owned farms or had been transferred to the State Land Fund in return for a pension (Milczarek, 2000). By the end of 1996 the Agency had taken over about 4.5 million hectares as well as accompanying fixed and current assets (Safin and Guba, 2000).

As the size of family farms has been historically small in Poland, estimating the number of farm holdings is problematic. The 1996 Polish Agricultural Census defined agricultural holdings as units with at least one hectare of land but recorded the number of units below this threshold. On this basis, it was estimated that there were just over one million holdings with between 0.1 and 1.0 hectares of land, occupying less than $2.2 \%$ of TAA. Just over two million holdings of greater than 1 hectare were recorded (Table 1). The majority of these holdings are of less than five hectares. At the same time, about $35.7 \%$ of the total agricultural area was cultivated by $8.4 \%$ of all farms, each with more than 15 hectares (Safin and Guba, 2000). Estimates by Szemberg (1999) suggest that only farms above 15 hectare can generate an income above the poverty line for one full-time person. Farms with less than five hectares are heavily dependent on other off-farm sources of employment or social security benefits.

As recorded in Table 1, the number of farm holdings has steadily decreased in the 1990s, from over 2.1 million in 1990 to 1.99 million in 1998. This trend reflects a withdrawal of labour from agriculture in a period of falling farm incomes caused by a cost-price squeeze and fall in real government protection to agriculture. However, it should be noted that despite the worsening terms of trade, the rate of withdrawal has been relatively slow: the number of holdings has declined by about 0.7 per cent per annum. Looking at changes within size cohorts 
an interesting polarisation is apparent. The number of 1 to 2 hectare holdings has risen from 378,300 to 449,500 since 1990 and the number of holdings with 15 hectares or more has also grown. In contrast, the number of medium sized farms (by Polish standards) has fallen considerably, especially in the 5 to 10 hectare category. A number of factors have led to this trend. First, land sales have seen a reallocation of land to some larger producers especially where there has been a degree of foreign investment. Second, farmers' pensions are generous by Polish standards. To qualify for a farmer's pension an individual must farm more than one hectare. There is some evidence that in some cases the purchase of farm holdings or how they have been registered has been influenced by household strategies to qualify for farmers' pensions (Szemberg, 1999). This polarisation has left Poland with a wide array of farm sizes which has potentially far reaching consequences for competitiveness and a methodology for investigation is presented in the next section.

\section{METHODOLOGY}

\section{Domestic Resource Costs (DRCs)}

The DRC ratio is a measure of the relative efficiency of domestic production. The DRC measures the relative efficiency of domestic production in terms of its international cost competitiveness. The DRC compares the opportunity costs of domestic production to the value added it generates (Tsakok, 1990). The numerator is the sum of the costs of using domestic primary resources - land, labor and capital - and of non-traded inputs. The denominator is the value-added in border prices. The DRC for the production of commodity $i$ in Poland is calculated as: 


$$
D R C_{i}=\frac{\sum_{j=k+1}^{n} a_{i j} V_{j}}{P_{i}^{r}-\sum_{j=1}^{k} a_{i j} P_{j}^{r}}
$$

where $a_{i j}, k+1$ to $n$ are the technical coefficients for domestic resources and non-tradable intermediary inputs and $V_{j}$ are the social prices of domestic resources and non-tradable inputs, necessary to estimate the opportunity costs of domestic production. $P^{r}{ }_{i}$ is the border / reference price of traded output, $a_{i j} l$ to $k$ are the technical coefficients for traded inputs and $P^{r}{ }_{j}$ are the border / reference prices of traded inputs. When the DRC is smaller than 1 , domestic production is efficient and internationally competitive, because the opportunity cost of spent domestic resources is smaller than the net foreign exchange it gains in export or saves by substituting for imports. The opposite is true when the DRC is larger than 1 . The balanced case is when DRC equals 1. Then the economy neither gains, nor saves foreign exchange through domestic production. DRCs are widely used in policy analysis as they give an indication of the degree to which domestic production is internationally efficient, suggesting where policies should be targeted (Tsakok, 1990).

\section{DATA SOURCES AND ASSUMPTIONS}

In assessing the competitiveness of Polish agricultural products, eight main commodities are considered (bread wheat, rye, sugar beet, rapeseed, potatoes, milk, beef and pork meat). These products were chosen because of their relative importance in Polish agricultural output. The estimation of DRCs utilised a number of data sources: the statistical yearbooks of Poland, agricultural statistical yearbook, statistical yearbook of foreign trade, custom office data, Agency for Agricultural Markets data and industry estimates, habour information on port charges and Instytut Ekonomiki Rolnictwa i Gospodarki Zywnosciowej (IERiGZ) farm level 
survey data. ${ }^{1}$ IERiGZ conduct a survey to just over 1,000 farms annually, collecting information on input and output prices, quantities and yields. In addition, information on the five largest farms analysed is derived from questionnaires prepared by the authors.

\subsection{Output Prices}

Social prices for outputs and tradable inputs were taken as border prices (export / import parity prices), adjusted to the farm level by port and handling charges, transport, storage and maintenance costs (where appropriate). The adjusted border prices are seen to be appropriate social prices for outputs and tradable inputs because these price represent the opportunity costs of domestic production. For non-traded inputs (factors of production) because they are not normally traded internationally, adjusted border prices cannot be used for deriving social prices. For these factors (land, labour and capital) their social price is said to be its value in a realistic alternative use (i.e. the social price of unskilled labour in agriculture is taken to be the average wage of unskilled labour in manufacturing). Import and export data was taken from Glówny Urzad Cel. Port charges are based on information from the enterprise Port Ustka and the enterprise Port Gdansk. For products for which Poland is a net exporter, an average f.o.b. export parity price was taken as the unadjusted reference price. For products for which Poland is a net importer, average c.i.f. import parity prices were used.

Two problems may emerge with the selection of import and export parity prices. First, a problem may arise where the farm level good is not traded internationally (as with liquid milk). For Poland the export parity price for skimmed milk powder (SMP) was taken (as Poland is a net exporter), which was adjusted back to farm level with an adjustment for the prevailing processing margin and conversion coefficient between raw milk and SMP. A second issue

\footnotetext{
${ }^{1}$ IERiGZ (Institute of Agricultural Economics and Food Economy, Warsaw)
} 
may arise where the quality of the traded good differs from the quality of domestic production. This is not so much of an issue when the export parity price is taken as the lower quality will be reflected in lower unit values at the border. For import parity prices the issue however remains so that where the quality of Polish production was recognised as being lower than the imported equivalent, a suitable price adjustment was made.

\subsection{Input Prices}

Private input prices and quantities together with information on yields were taken from the IERiGZ surveys and the questionnaires to the largest five producers. The IERiGZ sample was divided into two groups: small farms (3-10 hectares) and medium sized farms (greater than 10 hectares (Table 2). The largest five farms were selected to give a flavour of the best performers in Poland but should not be treated as representative. All the private prices used were average national prices, and no substantial analysis on a regional or sub-regional level was made.

Labour costs were based on zloty values with different levels for skilled and unskilled labour. The social value of unskilled labour employed in labour was taken to be the wage of unskilled workers in the industrial sector. The social value of skilled labour was taken to be the average wage rate of skilled labour in industry. The opportunity cost of capital is based on the observed real interest rate obtainable following the approach detailed in Monke and Pearson (1989).

The social price of land should be measured as its rental value in the most profitable alternative agricultural use. For example, if rye production were to represent the only alternative to wheat production, the social cost of land for the wheat activity would be represented by the social 
profits (excluding land) from the production of rye (Monke and Pearson, 1989). However, a single clear alternative is often not evident as systems vary in terms of riskiness and the desirability of crop rotation. Following Pearson et al. (1987), an average of suitable commodity alternatives was taken for deriving social land prices, as social values would probably fall somewhere in this range.

\subsection{Farm Structure}

For all the products analysed, the DRCs were estimated for the three farm size groups. Such disaggregation helps take into account the variations in input use, yields and other production costs between farm sizes. For each size group, DRCs were estimated for the years 1996 to 1998. Table 3 records the average area devoted to particular commodities or average number of animals by the three farm types analysed, as estimated by IERiGZ officials.

\subsection{Marginal Production}

The closer the DRC to 1 , the more marginal is Poland's comparative advantage or disadvantage in the production of that particular commodity, and enterprises in this range are most susceptible to changes in world market prices and exchange rates. In contrast, the further the DRC is below 1, the more robust the level of international comparative advantage. It should be noted that the DRCs are estimated here are farm size averages. Some producers, especially those entering or leaving the sector as marginal enterprises, may be considerably more or less efficient than the average, and so vary in their susceptibility to adverse changes in international prices or exchange-rate shifts. Finally, denominators of all equation [1] like coefficients were evaluated in Polish zloty by using an average nominal exchange rate for the year in question. 


\section{RESULTS}

The results of the DRC estimations are presented by commodity per farm type in Table 4. On the basis of the structure of production in Poland (Table 5), average DRCs were calculated (Table 6). In Table 4, 72 cases are presented (3 farm types in 3 years for 8 commodities). From these 72 cases, there are 33 instances of DRCs of less than 1 (internationally price competitive). If one compares livestock with arable production, a clear distinction is evident. Out of 27 cases in the livestock sector, there are only 6 instances of DRCs below 1 (22 per cent). In contrast, 27 cases of international competitive arable production are reported (60 per cent). In general, the degree of competitiveness worsened during the period 1996 to 1998 . For example in 1996, 1997 and 1998 there were 15, 12 and 6 cases of DRCs of less than 1 respectively. These results highlight the fall in international commodity prices during this period. A variation between farm sizes is also apparent. Considering the small farm cohort, only 6 cases of internationally competitive production are recorded: in contrast the comparable figures for medium and large farms is 11 and 16 cases respectively. This farm size variation echoes similar work on large farms being more internationally competitive in the CEECs (Banse et al., 1999). However, one must consider the degree to which the comparative advantage or disadvantage in a particular case is marginal. The problems mentioned about social prices of domestic factors, biases in farm surveys and exchange rate sensitivity suggest that results about marginal cases might be misleading.

\section{Commodity Results}

In 1996 all three farm sizes were internationally competitive in the production of wheat. By 1998, only the large farms were internationally competitive. In each of the three years there is a clear pattern of an inverse relationship between DRCs and farm size. The weakening of internationally competitiveness of Polish wheat production does not reflect worsening 
technical coefficients but rather falls in border prices. In 1997 average world wheat prices decreased by more than 10 per cent $(F A O, 1998)$ and fell again in 1998. This fall reduced the measured competitiveness of CEEC grain production by making the traded output less valuable.

Polish rye production was comparatively less competitive than wheat, for the years analysed. In no year was rye production on small farms internationally competitive and in 1998 for none of three farm sizes was DRCs lower than 1. As with wheat, the DRCs for rye worsened during the period as border prices fell. Private profitability of wheat and rye production also fell during the period analysed: for example the nominal price wheat and rye fell by 7.7 and 12 per cent respectively in 1998 (GUS, 1999).

For oilseed rape and potatoes the picture was better. In all cases, except small farms in 1998, the DRCs for oilseed rape were less than 1. For potatoes in all cases and all farm types DRCs were estimated as being less than 1 . The higher private profitability of rapeseed relative to wheat and rye led to an increase in sown area between 1996 and 1999. For both commodities an inverse relationship between DRCs and farm size was again recorded. The larger farms use fewer units of non-traded factors of production per unit of tradable cost than smaller farms. However, this pattern is sensitive to the social cost of land adopted. A higher social price of land tends to reduce the tendency for the larger structures to have lower DRCs (Hughes, 1998). Considering the technical coefficients adopted, Polish agriculture is characterised by low use of tradable inputs. In 1998, the average amount of NPK (nitrogen/phosphorous/potassium) fertilisers used per hectare of arable land was $89.6 \mathrm{~kg}$ of NPK (about 1/3 of the amount used in 1990). The average use of pesticides was $0.62 \mathrm{~kg}$ of active agent per one hectare of arable land. As a result yields are comparatviely low, esepcially on small farms. 
Sugar beet production is not socially profitable and is effectively protected. Output prices are above adjusted border prices and profits at social prices would be negative (Table 6). The DRC is significantly above 1 , and it is difficult to envisage the bulk of sugar beet production in Poland being internationally competitive.

Overall, livestock DRCs are higher than for crops and this pattern mirrors the results for other CEECs (Banse et al, 1999; Gorton et al. 2000). Pork production was only internationally competitive on large farms in 1996 and 1997. During this period both international prices and private profitability fell in real terms. In 1997 there was a downward phase in the pork cycle, which combined with a significant growth in private cereal prices, accompanied by low prices of swine worsened profitability ratios. ${ }^{2}$

The DRCs for beef are all above 1 except for medium and large farms in 1996. Polish beef and veal production has fallen sharply since 1990 and this trend continued until 1998 albeit at a slower rate. Beef recorded the steepest decline in output of all of the major meats. Private output prices have been unstable but in general not kept pace with general inflation, fat content is high and a large share of meat is used for low quality processed goods (sausages, smoked meats etc.). By 1996, beef constituted only one-seventh of total meat consumption in Poland, equivalent to $10 \mathrm{~kg}$ per capita per annum. Such a level was $40 \%$ lower than five years

21998 was a difficult year for pork producers throughout Europe. International overproduction was reflected in very low import parity prices. 
previously and $50 \%$ lower than the record one of $1976-1977 .{ }^{3}$ It is unlikely that small beef producers will be internationally competitive in the foreseeable future.

Milk production was only competitive on large farms in 1996 and 1997. The DRCs for milk and beef production on small farms are comparatively high: for example the DRCs for beef and milk in 1998 were 4.52 and 4.36 respectively. ${ }^{4}$ As with crops, international competitiveness worsened during the period analysed for livestock products as border prices fell. For example, in 1996 international beef prices fell due to the BSE crisis and have not recovered (FAO, 1998). Polish private prices also fell in real terms during 1998 as the EU imposed an export ban on dairy products from Poland and demand from Russia fell (IERiGZ, 1999). The industry as a whole recorded a loss with co-operatives and smaller enterprises worst affected.

The fall international prices was only partially transmitted to Polish producers as the level of protection, measured in terms of nominal protection rates (NPRs) ${ }^{5}$ rose during the period.

${ }^{3}$ Some slight improvement has, however, been recorded recently in the beef sector. The population of young breeding cattle is increasing and both breeders and processing plants have become more interested in better breeds for meat production.

${ }^{4}$ A price adjustment was made in the case of milk from small farms to reflect a differential in quality. The milk that is sold to dairies by small farms tends to have high bacterial cell counts due to the lack of proper cooling facilities, and in some cases the poor quality of the raw material renders it only suitable for manufacturing cheese.

${ }^{5}$ The NPR is an indicator of the differential between domestic and international prices for an agricultural commodity. For commodity $i$ (in \%):

$$
N P R_{i}=\left(\frac{P_{i}^{d}}{P_{i}^{b}}-1\right) * 100=\left(N P C_{i}-1\right) * 100
$$


Domestic private agricultural prices fell in real terms between 1998 before recovering in the second half of $1999 .^{6}$ The latter was due in part due to substantially smaller harvests than the previous year, particularly for cereals (buoyed by Agricultural Market Agency intervention buying), potatoes and pigs (GUS, 2000).

\section{Farm Size and DRCs}

The DRC estimates consistently indicate that larger farms are more internationally competitive as they use fewer units of non-traded factors of production per unit of tradable cost and achieve higher yields. However, as discussed earlier, the structure of production in Poland is still highly fragmented and antagonistic toward being internationally competitive. For example, 32 per cent and 41 per cent of the Polish wheat and rye crop are grown on small farms (less than 10 hectares) respectively (Table 5). There is a bulk of small units cultivating up to 5 ha and a limited number of larger units with over 25 ha of arable land. A similar problem is apparent for milk production. The average milk farm (in most cases milk is not the main or only activity) is about 5.2 ha of agricultural land with 3.4 milk cows. These small producers lack proper machinery, equipment and reasonable housing conditions (IERiGZ 1998a, 1998b). Production is skewed to grassland rearing with inappropriate feeding regimes (based on hay rather than silage).

\section{CONCLUSIONS}

where $\mathrm{P}_{\mathrm{i}}^{\mathrm{d}}$ is the domestic price and $\mathrm{P}_{\mathrm{i}}^{\mathrm{b}}$ is the adjusted border price (or reference price) of output $i$.

${ }^{6}$ For each year between 1996 and 1999 the terms of trade for Polish agriculture worsened as private tradable costs rose faster than private output prices. During this period, the consumption of fertilisers and purchases of certified seeds declined. 
The degree to which the agricultural sector can compete on international and EU markets is of vital importance to Poland. This paper has presented a comparative analysis of competitiveness based on an accounting procedure (DRCs). The results highlight that for the period 1996 to 1998 Polish crop production was more internationally competitive than livestock farming. This mirrors the results for other CEECs (Gorton et al. 2000). The most internationally competitive crops of those analysed were rapeseed and potatoes. During the period, however, international competitiveness worsened as international commodity prices fell. Polish producers felt the effects of this through lower private domestic prices although they were shielded from the full effects by increasing levels of protection. The average DRC values for livestock products were all consistently above unity, although pork production comes closest to being competitive at world prices.

There is a consistently inverse relationship between DRCs and farm size that held for all commodities and all years. This is an important result as Polish production is relatively fragmented and the degree of structural change has been slow. Looking at the at what structural change has occurred, the relative shift to larger farms as a percentage of the total agricultural area (TAA) has been much greater than the increase in the number of large farms (Table 1). One reason for this is that existing larger farms have grown through additional leasing agricultural land. In contrast, financial constraints have limited the ability of potentially new or existing small farmers to purchase and equip large holdings especially in a period of low profitability. The creation of new large farms, given the present farm structure tends to require the purchase of land from a number of individuals and families. The latter is hampered by the low level of alternative job opportunities in rural Poland. While farm incomes are low, the opportunity costs of farming, especially by the elderly and unskilled are not high. The degree to which alternative jobs are created in rural areas will in part determine the speed with 
which individuals leave the agricultural sector and hence the process of structural change in farming.

For the period analysed, many commodities were privately and socially uncompetitive and overall, agriculture is a loss-making sector (GUS, 1999). Many enterprises have responded to falls in margins by reducing the use of tradable inputs. This can only however be a short-term response. In the long term competitiveness can only be improved by supporting the modernisation of production, amalgamation of farm units and encouraging the establishment of marketing organisations to improve value added and guide improved output mixes.

\section{References}

Banse, M., Gorton, M., Hartell, J., Hughes, G, Köckler, J., Möllman, T. and Munch, W. (1999), The Evolution of Competitiveness in Hungarian Agriculture: from Transition to Accession, paper presented the IXth European congress of Agricultural Economists, Warsaw, Poland, 24 th -28 th August.

Bureau, J. C. and Kazlaitzandokanes, N. G. (1995) 'Measuring Effective Protection in European Agriculture', American Journal of Agricultural Economics, Vol.77, pp.279290

European Union (1998) Agricultural Situation and Prospects in the Central and Eastern European Countries. Agriculture and Rural Development, Working Documents.

EU DG06 (1999) Agricultural Statistics on-line database. Internet address: http://europa.eu.int/comm/dg06/agrista/table_en/2012.pdf

FAO (1998), Commodity Market Review 1997-98, Rome: FAO

Gorton, M., Davidova, S. and Ratinger, T. (2000). 'The Competitiveness of Agriculture in Bulgaria and the Czech Republic vis-à-vis the European Union', Comparative Economic Studies, XLII, (1), 59-87.

GUS (1985-1999). Biuletyn Statstyczny / Statistical Yearbook, various issues, Warsaw GUS (1998). Rocznik statystyczny rolnictwa, Warsaw: Glównego Urzedu Statystycznego 
GUS (2000). Ceny Produktow Rolnych 1999, Warsaw: Glównego Urzedu Statystycznego

Hughes, G. (1998). Agricultural Productivity and Farm Structure in the Czech Republic. Working Paper 2/7. University of London, Wye College, Kent, U.K.

IERIGZ, (1997). Handel Zagraniczny Produktami Rolno-Spozywczymi stan i perspektywy, Nr.6, Pazdziernik

IERIGZ, (1998a). Rynek Mleka stan i perspektywy, Nr.14, Maj

IERIGZ, (1998b). Rynek Mleka stan i perspektywy, Nr.15, Pazdziernik

IERIGZ, (1999). Rynek Mleka stan i perspektywy, Nr.16, Maj

MAFE, (1999), Agriculture and food Economy in Poland, Warsaw: Ministry of Agriculture and Food Economy

Milczarek, D., (2000). The Privatisation of State Farms in Poland - A New Institutional Approach, paper presented to the KATO Symposium on Understanding Transition of Central and Eastern European Agriculture Humboldt-Universität zu Berlin, $2^{\text {nd }}-4^{\text {th }}$ November

Monke, E.A. and Pearson, S.R. (1989). The Policy Analysis Matrix for Agricultural Development, Ithaca: Cornell University Press.

Pearson, S.R. et al. (1987). Portuguese Agriculture in Transition, Ithaca: Cornell University Press.

Safin, M. and Guba, W. (2000). Data on farm structure in Poland. EU Network of Indepednet Agricultrual Exports in the CEEC Candidate Countries, Issue paper for Poland, No.1

Szemberg, A. (1999). 'Individual farming in Poland', Zagadnienia Ekonomiki Rolnej, special issue No.2-3, pp. 32-46.

Tsakok, I. (1990). Agricultural Price Policy: A Practitioner's Guide to Partial-Equilibrium Analysis. Ithaca and London: Cornell University Press 
Table 1: Polish farm structure by size classes, 1990-1998

\begin{tabular}{|c|c|c|c|c|c|}
\hline & 1990 & 1995 & 1996 & 1997 & 1998 \\
\hline \multicolumn{6}{|c|}{ Number of holdings by size class ('000 holdings) } \\
\hline Total & 2137.5 & 2047.6 & 2041.4 & 2008.3 & 1989.0 \\
\hline 1 to 2 hectares & 378.3 & 428.8 & 462.2 & 439.2 & 449.5 \\
\hline 2 to 5 hectares & 750.8 & 690.3 & 667.6 & 691.0 & 676.3 \\
\hline 5 to 10 hectares & 636.3 & 545.2 & 520.8 & 503.1 & 491.3 \\
\hline 10 to 15 hectares & 242 & 219.5 & 217.2 & 206.2 & 202.9 \\
\hline 15 hectares and more & 130.1 & 163.8 & 173.6 & 168.8 & 169.1 \\
\hline \multicolumn{6}{|c|}{ Agricultural area by farm size class ('000 hectares) } \\
\hline Total & 13399.8 & 13819.9 & 14259.5 & 13936.5 & n.a.** \\
\hline 1 to 2 hectares & 563.7 & 618.3 & 650.6 & 630.3 & n.a. \\
\hline 2 to 5 hectares & 2504.0 & 2275.5 & 2199.1 & 2263.3 & n.a. \\
\hline 5 to 10 hectares & 4622.9 & 3865.3 & 3713.3 & 3575.0 & n.a. \\
\hline 10 to 15 hectares & 2996.0 & 2655.8 & 2631.5 & 2499.0 & n.a. \\
\hline 15 hectares and more & 2713.2 & 4405.0 & 5065.0 & 4968.9 & n.a. \\
\hline
\end{tabular}

Source: Safin and Guba (2000) based on data from GUS (1998). 
Table 2. Sample of farms included in the analysis

\begin{tabular}{|c|c|c|c|c|c|c|}
\hline \multirow[t]{2}{*}{ Products } & \multirow[t]{2}{*}{ Constraint } & \multirow[t]{2}{*}{ Year } & \multicolumn{4}{|c|}{ Number of farms } \\
\hline & & & \begin{tabular}{|l} 
total \\
\end{tabular} & small & medium & large \\
\hline \multirow[t]{3}{*}{ Wheat } & \multirow[t]{3}{*}{ area $>0.2$ ha } & 1996 & 805 & 240 & 560 & 5 \\
\hline & & 1997 & 801 & 240 & 556 & 5 \\
\hline & & 1998 & 786 & 222 & 559 & 5 \\
\hline \multirow[t]{3}{*}{ Rye } & \multirow[t]{3}{*}{ area $>0.2 \mathrm{ha}$} & 1996 & 547 & 164 & 378 & 5 \\
\hline & & 1997 & 525 & 165 & 355 & 5 \\
\hline & & 1998 & 528 & 154 & 369 & 5 \\
\hline \multirow[t]{3}{*}{ Rapeseed } & \multirow[t]{3}{*}{ area $>0.2 \mathrm{ha}$} & 1996 & 80 & 5 & 70 & 5 \\
\hline & & 1997 & 83 & 4 & 74 & 5 \\
\hline & & 1998 & 116 & 13 & 98 & 5 \\
\hline \multirow[t]{3}{*}{ Potatoes } & \multirow[t]{3}{*}{ area $>0.2$ ha } & 1996 & 728 & 208 & 515 & 5 \\
\hline & & 1997 & 677 & 187 & 485 & 5 \\
\hline & & 1998 & 651 & 164 & 482 & 5 \\
\hline \multirow[t]{3}{*}{ Sugar beets } & \multirow[t]{3}{*}{ area $>0.2$ ha } & 1996 & 304 & 70 & 229 & 5 \\
\hline & & 1997 & 266 & 49 & 212 & 5 \\
\hline & & 1998 & 234 & 37 & 192 & 5 \\
\hline \multirow[t]{3}{*}{ Pork } & \multirow[t]{3}{*}{ sale $>1500 \mathrm{~kg}$} & 1996 & 780 & 216 & 559 & 5 \\
\hline & & 1997 & 767 & 231 & 531 & 5 \\
\hline & & 1998 & 759 & 209 & 545 & 5 \\
\hline \multirow[t]{3}{*}{ Beef } & \multirow[t]{3}{*}{ sale $>500 \mathrm{~kg}$} & 1996 & 701 & 187 & 509 & 5 \\
\hline & & 1997 & 696 & 186 & 505 & 5 \\
\hline & & 1998 & 645 & 152 & 488 & 5 \\
\hline \multirow[t]{3}{*}{ Milk } & \multirow[t]{3}{*}{ sale > 5000 l } & 1996 & 832 & 292 & 535 & 5 \\
\hline & & 1997 & 823 & 293 & 525 & 5 \\
\hline & & 1998 & 786 & 266 & 515 & 5 \\
\hline
\end{tabular}

Sources: IERiGZ, calculations by authors 
Table 3. Average area devoted to particular commodity or average number of animals by farm type in the Sample of farms analysed

\begin{tabular}{|c|c|c|c|c|c|}
\hline \multirow[t]{2}{*}{ Products } & \multirow[t]{2}{*}{ Constraint } & \multirow[t]{2}{*}{ Year } & \multicolumn{3}{|c|}{ Average area / number of animals in farms: } \\
\hline & & & small & medium & large \\
\hline \multirow[t]{3}{*}{ Wheat $^{1}$} & \multirow[t]{3}{*}{ area $>0,2$ ha } & 1996 & 1.01 & 7.45 & 300 \\
\hline & & 1997 & 1.08 & 8.49 & 320 \\
\hline & & 1998 & 1.05 & 8.69 & 320 \\
\hline \multirow[t]{3}{*}{ Rye $^{1}$} & \multirow[t]{3}{*}{ area $>0,2$ ha } & 1996 & 0.67 & 3.51 & 60 \\
\hline & & 1997 & 0.66 & 3.28 & 55 \\
\hline & & 1998 & 0.65 & 3.66 & 60 \\
\hline \multirow[t]{3}{*}{ Rapeseed $^{1}$} & \multirow[t]{3}{*}{ area $>0,2$ ha } & 1996 & 0.02 & 1.27 & 80 \\
\hline & & 1997 & 0.01 & 1.28 & 75 \\
\hline & & 1998 & 0.06 & 2.23 & 80 \\
\hline \multirow[t]{3}{*}{ Potatoes $^{1}$} & \multirow[t]{3}{*}{ area $>0,2$ ha } & 1996 & 0.62 & 1.52 & 30 \\
\hline & & 1997 & 0.56 & 1.39 & 35 \\
\hline & & 1998 & 0.52 & 1.29 & 25 \\
\hline \multirow[t]{3}{*}{ Sugar beets ${ }^{1}$} & \multirow[t]{3}{*}{ area $>0,2$ ha } & 1996 & 0.19 & 1.29 & 140 \\
\hline & & 1997 & 0.15 & 1.25 & 130 \\
\hline & & 1998 & 0.13 & 1.23 & 140 \\
\hline \multirow[t]{3}{*}{ Pork $^{2}$} & \multirow[t]{3}{*}{ sale $>1500 \mathrm{~kg}$} & 1996 & 14.32 & 70.04 & 650 \\
\hline & & 1997 & 14.59 & 72.44 & 680 \\
\hline & & 1998 & 14.33 & 87.43 & 675 \\
\hline \multirow[t]{3}{*}{ Beef $^{2}$} & \multirow[t]{3}{*}{ sale $>500 \mathrm{~kg}$} & 1996 & 1.39 & 3.85 & 60 \\
\hline & & 1997 & 1.34 & 4.08 & 55 \\
\hline & & 1998 & 1.26 & 3.77 & 60 \\
\hline \multirow[t]{3}{*}{ Milk $^{3}$} & \multirow[t]{3}{*}{ sale $>50001$} & 1996 & 1.95 & 4.65 & 110 \\
\hline & & 1997 & 1.86 & 5.10 & 118 \\
\hline & & 1998 & 1.76 & 5.23 & 120 \\
\hline
\end{tabular}

\footnotetext{
Notes

${ }^{1}$ Average area (hectares) of selected crop

2 Average number of animals sold per annum

${ }^{3}$ Average number of milking cows in herd

Sources: IERiGZ, calculations by authors
} 
Table 4: DRC Estimates by Farm Type for Poland (1996-1998)

\begin{tabular}{|l|ccc|cccc|ccc|}
\hline & \multicolumn{3}{|c}{1996} & \multicolumn{3}{c|}{1997} & \multicolumn{3}{c|}{1998} \\
Wheat & Small & Medium & Large & Small & Medium & Large & Small & Medium & Big \\
Rye & 0.84 & 0.43 & 0.32 & 1.01 & 0.82 & 0.58 & 1.08 & 1.05 & 0.81 \\
Oilseed & 1.47 & 0.81 & 0.73 & 1.76 & 0.89 & 0.98 & 3.00 & 2.38 & 1.24 \\
Potatoes & 0.90 & 0.84 & 0.69 & 0.78 & 0.72 & 0.56 & 1.16 & 0.93 & 0.64 \\
Sugar Beets & 0.75 & 0.56 & 0.49 & 0.61 & 0.57 & 0.46 & 0.91 & 0.73 & 0.55 \\
Pigs & 4.17 & 3.54 & 1.87 & 3.04 & 2.94 & 1.56 & 4.44 & 4.83 & 1.75 \\
Beef cattle & 1.83 & 1.66 & 0.78 & 2.01 & 1.77 & 0.96 & 2.30 & 2.19 & 1.12 \\
Milk & 1.47 & 0.99 & 0.76 & 3.76 & 2.48 & 1.82 & 4.52 & 3.22 & 2.52 \\
\hline
\end{tabular}

Source: authors' calculations

Table 5: Structure of production of specific agricultural products (1996-1998)*

\begin{tabular}{|l|rrr|rrr|rrr|}
\hline & \multicolumn{3}{|c}{1996} & \multicolumn{3}{c|}{1997} & \multicolumn{3}{c|}{1998} \\
Wheat & Small & Medium & Large & Small & Medium & Large & Small & Medium & Large \\
Rye & 33 & 39 & 28 & 32 & 39 & 28 & 32 & 40 & 28 \\
Oilseed & 41 & 43 & 16 & 40 & 44 & 16 & 40 & 44 & 16 \\
Potatoes & 6 & 20 & 74 & 6 & 21 & 74 & 5 & 21 & 74 \\
Sugar Beets & 60 & 38 & 2 & 59 & 38 & 2 & 59 & 39 & 2 \\
Pigs & 29 & 50 & 21 & 29 & 51 & 21 & 28 & 51 & 21 \\
Beef cattle & 36 & 56 & 8 & 35 & 56 & 8 & 35 & 57 & 8 \\
Milk & 41 & 54 & 5 & 40 & 55 & 5 & 40 & 55 & 5 \\
\hline
\end{tabular}

* Percentage of total production

Source: authors' calculations

Table 6: Average DRC indicators calculated on base of the structure of production for specific commodities products.

\begin{tabular}{llll} 
Commodity & \multicolumn{3}{c}{ Years } \\
& 1996 & 1997 & 1998 \\
Wheat & 0.53 & 0.81 & 0.99 \\
Rye & 1.07 & 1.25 & 2.45 \\
Oilseed & 0.73 & 0.61 & 0.73 \\
Potatoes & 0.67 & 0.59 & 0.83 \\
Sugar Beets & 3.38 & 2.70 & 4.08 \\
Pigs & 1.65 & 1.78 & 2.14 \\
Beef cattle & 1.18 & 2.95 & 3.71 \\
Milk & 1.66 & 2.04 & 3.32
\end{tabular}

Source: Authors' calculations 